Original article

\title{
COVID-19: Impact of Service and Food Quality on Student Satisfaction and Food Wastage in a Tunisian Canteen
}

\author{
Hanen Ben Ismail (i) a, ", Marouane Rezgui (i) a , Sarra Jribi (i) a , \\ Derine Dogui (i] ${ }^{\mathrm{b}} \&$ Hajer Debbabi (i) a \\ a Department of Agri-Food Industries, National Agronomic Institute of Tunisia, University of Carthage, Tunisia \\ ${ }^{a}$ Department of Analyses Et Essais Comparatifs, National Institute of Consumption (Inc), Tunisia
}

\begin{abstract}
The coronavirus disease (COVID-19) pandemic has led to far-reaching health, social, and economic consequences. In order to secure the safety of students and staff, the Ministry of Higher Education and Scientific Research has established general guidelines for University campuses including canteens, based on prevention and protective measures. Food wastage is a major global issue impairing food security. The objective of the present study was to evaluate these COVID-19 measures on food wastage in a Tunisian University canteen. Because of the COVID-19 crisis, the university canteen has changed their practices by setting up a meal bag service for lunch and dinner. Face to face interviews based on a structured questionnaire, were conducted during one month on 154 on 143 student respondents (mean age 23 years old, 76\% women) in June 2020, after COVID-19 lockdown lifting. Interestingly the COVID-19 crisis has positively impacted the students' awareness about food wastage since $28 \%$ of respondents declared not throwing away food and $55 \%$ claimed to have reduced their food waste levels. Most of respondents (72.4\%) have highly appreciated the new concept based on take-away. About $63.1 \%$ declared eating at least every other day at the canteen, and $67.8 \%$ going more often. Interestingly $93.1 \%$ claimed to have noticed improvements in the quality of food items. These changes were related to better food presentation ( $72 \%$ of respondents), better food safety (64\%), better overall sensory quality (36\%), whereas only $1 \%$ claimed not having observed any changes. Food quality service has been evaluated as very good by $45 \%$ of respondents, and quality of prepared foods as good by $43 \%$. However, although the COVID-19 measures allowed a reduction by $21 \%$ of self reported food wastage in the canteen, most of respondents (71.3\%) affirmed not finishing their plates. The most discarded dishes were soups (62\% of respondents), stews (52\%), vegetables (48\%) and salad (45\%) whereas dairy products (65.4\% of respondents), fruits (64.4\%), rice (51.9\%), Tunisian dish tajin (51.9\%) and chicken (50\%) were not wasted. In conclusion, our study has shown that providing good take-out meals has potential for reducing food wastage among students, strengthening the importance of food safety and convenience as effective tools for food waste prevention.
\end{abstract}

Keywords: Students, COVID-19, Food Service, Quality Of Food Products, Food waste.

Received:01 September 2020 * Accepted: 22 March 2021 * DOI: https://doi.org/10.29329/ijiaar.2021.339.4

\footnotetext{
* Corresponding author:

Hanen Ben Ismail is a PhD in food science, Hanen Ben Ismail is currently associate Professor at the National Agronomic Institute of Tunisia (University of Carthage). Head of the department od Agri-Food Industries, her areas of research are related to improving the quality of food (Risk management, Food microbiology, Toxicology and Hygiene) and to valorising the traditional food and indigenous agricultural resources. Tunisia. Email: benismailhanen@yahoo.fr
} 


\section{INTRODUCTION}

World food consumption has changed in recent years qualitatively and quantitatively. Indeed, collective and rapid caterings have become an important food consumption patter in developed and even in developing countries. In terms of quantities, urbanization and demographic growth (9.6 billion by 2050 (United Nations, 2014) lead to a large consumed quantity of fresh and processed food products. An increase in world agricultural production of $15 \%$ is forecast for 2030 (Deluzarche, 2020). This situation leads to significant food losses and waste. FAO (2011) estimated that 1.3 billion tons are wasted worldwide (equivalent to over 41 tons per second). While famine affects more than one in 10 people in the world, this food waste represents $30 \%$ of the human food requirement (WFP, 2019). Food waste has, obviously, environmental and social impacts, but above all it has economic consequences. Considering the increase of hunger and the restriction of natural resources, it becomes clear that waste management systems are an important challenge currently. Several solutions are possible such as awareness and prevention especially with women and young people who seem to be the most affected by this waste (Baig et al., 2019). Green policy can be an ex post solution aimed at improving recycling capacity and efficiency, provided recovery practices are improved.

This waste concerns not only production, harvesting, transport and storage but it also involves mainly processing, distribution and consumption (FAO, 2013). In Europe, the main food wastage is generated by households (53\%), food industries (19\%), collective catering (12\%) and by distribution (5\%) (European Parliament, 2017). In Near East and North Africa region, food waste has been estimated to $250 \mathrm{Kg}$ per year per individual and, at the consumption stage, to be $34 \%$ (FAO 2015). Food waste is also prevalent in Tunisia at the consumption stage, as reported by Sassi et al. (2016), Tunisian National Institute for Consumption (INC, 2017; 2018) and Jribi et al. (2020). Tunisian household waste represented 23.5\% of food supply in 2017 and cost 572 million Tunisian dinars (US \$197 million) (INC, 2018). Since food consumption patterns have changed nowadays, collective catering is also becoming a significant source of losses and waste. It can concern restaurants, caterers, cafeterias but also any type of canteen. This collective catering is a good means of meeting and sharing with a very interesting price and nutritional quality. However, it has been proven that it generates a lot of waste. Depending on the age of the consumers and the seasonal menu, food wasted in canteens can represent up to $30 \%$ of the meal prepared (García-Herrero et al., 2019). According to Tunisian National Institute for Consumption (INC 2018), food waste also affects $12 \%$ of food prepared in hotels and $16 \%$ of meals in restaurants. A study of Tunisian National Institute for Consumption (INC 2017), in collective or commercial restaurants has established that $74 \%$ of customers affirmed to complete their dish. Furthermore, in Tunisian University canteens, $83 \%$ of managers declared to have noticed food wastage in their establishments: in fact, an average of 6\% of the served meals is thrown away (FAO, 2018). This wasted food represents an economic loss as well as a loss in labor and resources such as energy, land and water. 
Moreover, wasting food increases greenhouse gas emissions and contributes to climate change. Considering the integrated impacts, food waste can be responsible worldwide for almost $18 \%$ of the Global Warming Potential and $11 \%$ of the costs (García-Herrero et al., 2019). In low- and middleincome countries like Tunisia, this wasted food could potentially feed people in need and thereby contribute to increase food security (Bachta 2011). This is why several strategies, action plans, and updated policies were set up by Tunisian government and local authorities (Mahjoub et al., 2020).

This waste can be related to several causes such as buffet service (as well as the use of trays), health regulations (which prohibit the consumption of not consumed served dishes) and especially dishes presentation (Falasconi et al., 2015). These social and environmental factors (meal catering services and consumption habits) differ from country to country and have a direct impact on the amount of generated food waste (Lorenz et al., 2017). Food waste management faces major challenges: in Tunisia there are problems linked to the lack of public awareness, reliable data, financing, operational enforcement, trained staff, and basic know-how (Mahjoub et al., 2020). Many means can be adopted to reduce food wasting in caterings such as controlling portions (Visschers et al., 2020), breaking down organic materials or donating and composting (Blackbun, 2019). Simple and inexpensive education and awareness campaigns can be used to raise consciousness and attention about reducing plate waste. In fact, simple message-type and social media-based interventions can be useful in improving behaviors and increasing the sustainability of canteens in universities (Soares Pinto et al., 2018).

The COVID-19 pandemic which marked the end of 2019 and the beginning of 2020 (WHO, 2020a) had consequences on consumers' behavior (Wang et al., 2020). Durante (2016) has reported that crisis situations can have psychological impacts and can affect consumers' habits. Indeed, concerning food waste management during the COVID-19 crisis, the work of Jribi et al. (2020) showed that Tunisian consumers seemed to have developed positive attitudes toward food waste prevention. This increased awareness could be probably related to socio-economical context (i.e. food availability, restricted movements, loss of income) during the first months of COVID-19 crisis, rather than environmental considerations (Pappalardo et al., 2020; Principato et al., 2020; Rodgers et al., 2021). Interestingly, Sarkis et al. (2020) and Severo et al. (2021) have identified this pandemic as an important vector in people's behavioral change toward sustainability.

In another hand, in order to ensure consumer safety all over the world, several measures of cleaning and prevention have been taken, especially in collective catering (Güner et al., 2020). It was strongly advised to avoid physical contact, respect physical distance of 2 meters ( 6 feet), prevent face to face positioning with others, and reduce contact time. People attending the canteens and rest/welfare areas must wash their hands thoroughly as per World Health Organization (WHO) recommendations before entering a room or an area. When the catering was on site, many canteens provided reusable cutlery, eating utensils, cups etc. to ensure proper hygiene measures. Some others provided pre-prepared 
and wrapped individual disposable boxes. All good hygiene and distancing practices must be applied (EHS, 2020).

In order to secure the safety of students and staff, the Tunisian Ministry of Higher Education and Scientific Research has established general guidelines for University campuses including canteens, based on prevention and protective measures. For instance, the university canteen "Les Jardins" of The National Institute of Agronomy of Tunisia (INAT), a public school of engineers (University of Carthage, Tunisia) has performed meals distribution in take-out service bags by kitchen employees. The objective of the present study was to evaluate these COVID-19 measures on food wastage in a Tunisian University canteen in order to recommend improvements and implement best practices towards food waste and in general sustainability.

\section{MATERIALS and METHODS}

\section{Study site and COVID-19 measures}

The research was conducted at a university canteen "Les Jardins" (INAT, University of Carthage, Tunisia). The study was approved and authorized by the Head of the Restaurant. Canteen workers, chefs and director are public employees. The unit serves approximately 150-300 customers per service, at very low prices (0.2 Tunisian Dinars, less than US\$ 0.07, thanks to Tunisian state subventions). Meals were established under dieticians' supervision and are composed by soup, salad, main dish (chicken or turkey or stew) with vegetables or starchy sides (rice, pasta), bread, and dessert (fruit or yoghurt or cheese). The canteen used the traditional meals production system "cook and serve", in compliance with safety standards. Before COVID-19, meals were served in iron trails by kitchen employees. Because of COVID-19, meals distribution was performed in take-out service bags by kitchen employees, without previous meals booking. Restaurant workers had to follow cautiously the food preparation safety standards already established, to regularly disinfect and clean food preparation and service areas and equipments, and to consider more frequent cleaning of high touch surfaces, in addition to regular hand washing and to social distancing (WHO, 2020a).

\section{Data collection and analysis}

In order to determine customers' satisfaction and perceptions of quality of food and services offered at the university canteen, two surveys consisted in face to face interviews based on a structured questionnaire, before COVID-19 crisis (sample 1) and after COVID-19 lockdown lifting (sample 2). A convenience sampling technique was used in this study.

Sample 1: A first survey was performed on 154 student respondents during 15 business days in March 2020, before COVID-19 crisis. 
Sample 2: The second survey was conducted on 143 student respondents during 15 business days in June 2020, after COVID-19 lockdown lifting.

Student canteen users were completed and returned the questionnaires, which reflected a response rate of respectively $4.1 \%$ for sample 1 and $4.8 \%$ sample 2 .

The first section aimed at collecting demographic data of canteen customers and their behavior characteristics (age, gender, frequency of visits to the canteen, and intention to continue eating at the cafeteria). The second section addressed mainly perception of food quality and service in the canteen before COVID-19 crisis (sample 1) and after the effects of implementation of COVID-19 measures (sample 2). The third section aimed at evaluating students' food waste awareness and behaviors before (sample 1) and after COVID-19 lockdown lifting (sample 2).

Primary data analysis consisted in frequency counts and percentages, using Excel software.

\section{RESULTS}

Demographic data is summarized in Table 1. As shown in Table 1, the sample 1 consisted of university students, $31 \%$ male and $69 \%$ female, with a mean age of 23 years old. By the way, $71 \%$ of respondents used regularly the canteen service, $2 \%$ seldomly and $27 \%$ never.

The sample 2 consisted of $26 \%$ male and $74 \%$ female respondents, with a mean age of 23 years old (Table 1). All respondents were university students. Among the 143 respondents, $73 \%$ have used the canteen service. Since the COVID-19 lockdown lifting, a large group of respondents (64\%) declared to use them systematically, at least every other day whereas others went to the canteen sporadically $(19 \%)$ or never $(16 \%)$. Interestingly $72 \%$ claimed to use more often the canteen services after the COVID-19 lockdown. Furthermore, a majority (60.6\%) of respondents declared to intend to continue having their meals at the university canteen, whereas about $3.8 \%$ claimed to stop eating at the canteen. 
Table 1. Demographic and behavior characteristics of survey respondents (Sample 1: $n=154$; Sample 2: $\mathrm{n}=143$ students)

\begin{tabular}{|c|c|c|}
\hline & \multicolumn{2}{|c|}{ \% Respondents } \\
\hline & Sample 1 (Pre-COVID-19) & Sample 2 (Post-COVID-19) \\
\hline $\mathrm{N}$ & 154 & 143 \\
\hline Mean age (Years old) & 23 & 23 \\
\hline \multicolumn{3}{|l|}{ Gender } \\
\hline Male & 31 & 26 \\
\hline Female & 69 & 74 \\
\hline \multicolumn{3}{|l|}{ Frequency of canteen visits } \\
\hline Always & 18 & 18 \\
\hline Often & 24 & 25 \\
\hline Every other day & 25 & 21 \\
\hline Seldom & 2 & 19 \\
\hline Never & 27 & 16 \\
\hline \multicolumn{3}{|l|}{$\begin{array}{l}\text { Intention to continue eating at the } \\
\text { canteen }\end{array}$} \\
\hline Yes & - & 60.6 \\
\hline No & - & 3.8 \\
\hline Maybe & - & 35.6 \\
\hline
\end{tabular}

In the COVID-19 context, aiming to meet safety requirements, the University canteen « Les Jardins » has decided to provide take-away food catering services, instead of usual plated meals. The safety measures for customers were mainly focused on hygiene and physical distancing.

Since consumers' perceptions for food quality are important for making decision associated with food consumption and therefore wastage, respondents were asked to evaluate overall quality in food products and service (Table 2) before (Sample 1) and after implementation of COVID-19 measures (Sample 2). Respondents rated their levels of quality perception using a 5 points scale (from $1=$ Poor to 5 = Excellent). Mean scores (MS) were also reported in Table 2. 
Table 2. Survey results on perception of Food Quality and Service before (sample Samp1, $n=154$ ) and after implementing COVID-19 safety measures, using a 5-points scale (from $1=$ Poor to $5=$ Excellent) (sample Samp2, n=143)

\begin{tabular}{|c|c|c|c|c|c|c|c|c|c|c|c|c|}
\hline \multirow{3}{*}{$\begin{array}{l}\text { Quality } \\
\text { attributes }\end{array}$} & \multicolumn{10}{|c|}{ Quality perception (\% respondents) } & \multirow{2}{*}{\multicolumn{2}{|c|}{$\begin{array}{c}\text { Mean Score } \\
\text { (MS/5) }\end{array}$}} \\
\hline & \multicolumn{2}{|c|}{$\begin{array}{l}\text { Poor } \\
\text { (1) }\end{array}$} & \multicolumn{2}{|c|}{$\begin{array}{c}\text { Fair } \\
(2)\end{array}$} & \multicolumn{2}{|c|}{$\begin{array}{c}\text { Good } \\
(3)\end{array}$} & \multicolumn{2}{|c|}{$\begin{array}{c}\text { Very good } \\
(4)\end{array}$} & \multicolumn{2}{|c|}{$\begin{array}{c}\text { Excellent } \\
(5)\end{array}$} & & \\
\hline & $\begin{array}{c}\text { Sam } \\
\text { p1 }\end{array}$ & $\begin{array}{c}\text { Sam } \\
\text { p2 }\end{array}$ & $\begin{array}{c}\text { Sam } \\
\text { p1 }\end{array}$ & $\begin{array}{c}\text { Sam } \\
\text { p2 }\end{array}$ & $\begin{array}{c}\text { Sam } \\
\text { p1 }\end{array}$ & $\begin{array}{l}\text { Sam } \\
\text { p2 }\end{array}$ & $\begin{array}{c}\text { Sam } \\
\text { p1 }\end{array}$ & $\begin{array}{l}\text { Sam } \\
\text { p2 }\end{array}$ & $\begin{array}{c}\text { Sam } \\
\text { p1 }\end{array}$ & $\begin{array}{l}\text { Sam } \\
\text { p2 }\end{array}$ & $\begin{array}{c}\text { Sam } \\
\text { p1 }\end{array}$ & $\begin{array}{c}\text { Sam } \\
\text { p2 }\end{array}$ \\
\hline $\begin{array}{l}\text { Overall } \\
\text { quality of } \\
\text { food } \\
\text { products }\end{array}$ & 19.5 & 4.0 & 49.4 & 11.0 & 26.0 & 43.0 & 4.5 & 36.0 & 0.6 & 6.0 & 2.2 & 3.2 \\
\hline $\begin{array}{l}\text { Hygienic } \\
\text { quality }\end{array}$ & 25.3 & 4.8 & 40.3 & 26.0 & 24.0 & 31.7 & 9.1 & 26.9 & 1.3 & 4.8 & 2.2 & 3.2 \\
\hline $\begin{array}{l}\text { Sensory } \\
\text { quality }\end{array}$ & 39.6 & 13.5 & 43.5 & 39.4 & 12.3 & 30.8 & 3.9 & 11.5 & 0.6 & 13.5 & 1.8 & 2.6 \\
\hline $\begin{array}{l}\text { Meal } \\
\text { Presentati } \\
\text { on }\end{array}$ & 46.1 & 8.7 & 34.4 & 18.3 & 17.5 & 37.5 & 1.9 & 28.8 & 0.0 & 8.7 & 1.8 & 3.1 \\
\hline $\begin{array}{l}\text { Portion } \\
\text { size }\end{array}$ & 25.3 & 15.4 & 35.7 & 39.4 & 27.3 & 30.8 & 8.4 & 10.6 & 3.2 & 15.4 & 2.9 & 2.3 \\
\hline $\begin{array}{l}\text { Food } \\
\text { variety }\end{array}$ & 32.5 & 23.1 & 39.6 & 39.4 & 21.4 & 24.0 & 5.8 & 9.6 & 0.6 & 23.1 & 2.0 & 2.5 \\
\hline $\begin{array}{l}\text { Overall } \\
\text { service } \\
\text { quality }\end{array}$ & 16.2 & 3.0 & 37.0 & 7.0 & 35.1 & 34.0 & 11.0 & 45.0 & 0.6 & 11.0 & 2.4 & 3.5 \\
\hline
\end{tabular}

Before COVID-19 crisis (Sample 1), respondents were unsatisfied by the overall quality of food products and service in the canteen as well as all the quality attributes, since all mean scores were under average (MS $<2.5)$. The lowest scores (MS $=1.8$ ) were got by sensory quality, rated as fair by $43 \%$ of respondents and by meal presentation, rated as poor by $46 \%$ of respondents.

Implementation of COVID-19 safety measures has improved overall respondents' satisfaction (Sample 2) regarding the quality of food products presented and serve at the canteen (respectively MS=3.2 and 3.5). Overall quality of food items was evaluated as good by $43 \%$ of respondents and as very good by $36 \%$, whereas overall perception regarding the service quality presented at the university canteen was rated as good by $34 \%$ of respondents and as very good by $45 \%$.

With COVID-19 new measures (Sample 2), most of respondents were satisfied with the hygienic quality (MS =3.2) and the meal presentation ( $M S=3.1)$, respectively rated as good to excellent by $69.1 \%$ and $73.1 \%$ of respondents. Sensory quality of food products (MS $=2.6)$, as well as the menu variety (MS=2.5) showed the average mean score among the quality attributes and $39.4 \%$ of respondents rated these attributes as fair. The portion size recorded the lowest mean score $(M=2.3)$, below average, and was evaluated as fair by $39.4 \%$ of respondents. Our data indicated that overall quality of food products was mainly associated to meal presentation $\left(\mathrm{R}^{2}=0.9534\right)$ and to hygienic quality $\left(\mathrm{R}^{2}=0.6856\right)$.

Table 3 indicated students' perception of food and service quality after COVID-19 implemented measures (sample 2) in the University canteen. 
Table 3. Survey results on appreciation of the COVID-19 safety measures on canteen quality service (sample 2, $\mathrm{n}=143$ students)

\begin{tabular}{lrc}
\hline After COVID-19 implemented measures & \% of respondents \\
\hline Appreciation of the concept Take-out & Excellent & 64 \\
& Very good & 24 \\
Good & 4 \\
Fair & 4 \\
Changes in food quality and service & Poor & 4 \\
Nature of these changes in food quality and service & 92 \\
Better food presentation & 8 \\
Better food safety & 72 \\
More variety in food items & 64 \\
Better overall sensory quality & 46 \\
Less food quantity & 36 \\
No change & 1 \\
\hline
\end{tabular}

Most of respondents (88\%) have positively appreciated the concept of take away in meal service bags. About $92 \%$ declared that there were changes in food quality and service after the implementation of COVID-19 safety measures. Respondents have noticed an improvement in food presentation (72\%), in food hygiene (64\%), and in sensory quality (36\%), as well as more variety in food items (64\%).

Regarding food waste awareness, almost of respondents (98\%) affirmed to be aware of food waste issue before COVID-19 crisis. Most of respondents declared to avoid (28\%) or reduce (55\%) their food wastage since the COVID-19 crisis, whereas $17 \%$ stated not be concerned by this issue. Interestingly, COVID-19 crisis has led to a reduction in food waste at the canteen since there was a $21 \%$ decrease in respondents affirming not finishing their plates (Figure 1).

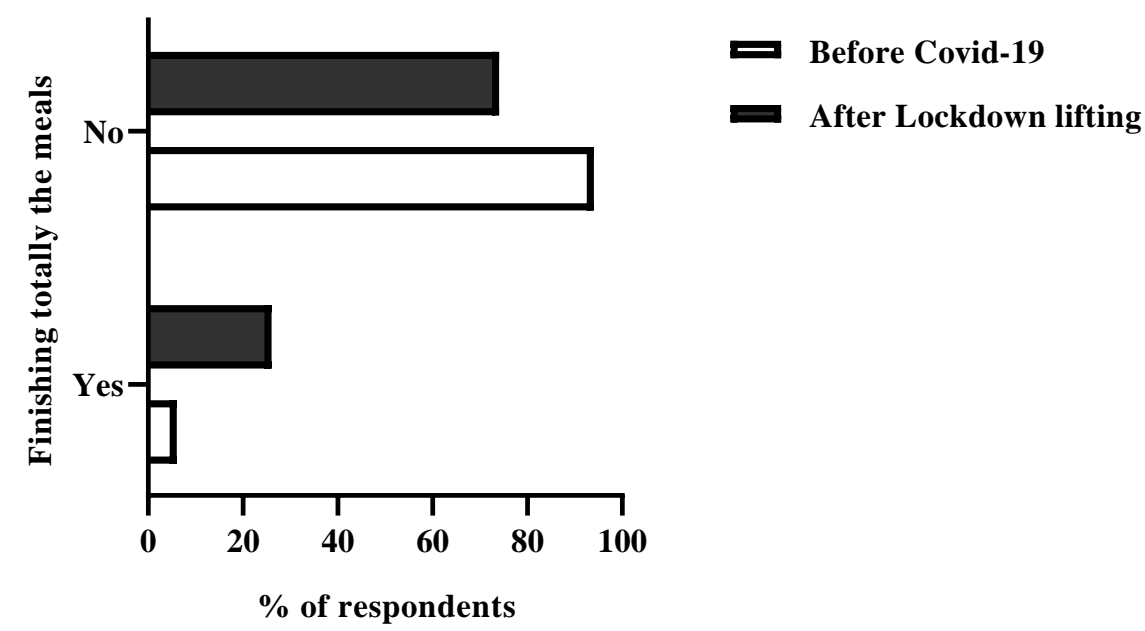

Figure 1. Food waste attitude at the canteen before (sample 1) and after implementing COVID-19 measures (sample 2). 
Regarding food item categories, dairy products and fruits were the least discarded food products, while vegetables, stews, and soups were the most discarded items. With COVID-19 measures, rice, tajin, chicken, turkey and pasta were less discarded when compared to before COVID-19 crisis (Figure 2). Moreover, there was a reduction of waste in soups and stews, although the amounts of discard remained high. In contrast, vegetables were more thrown away.

A.

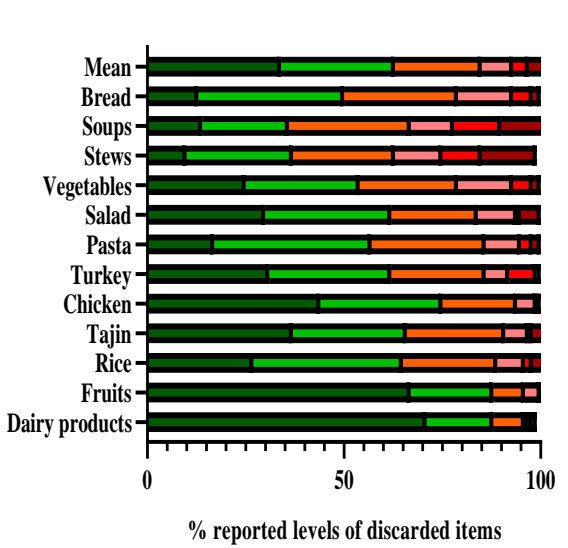

B.

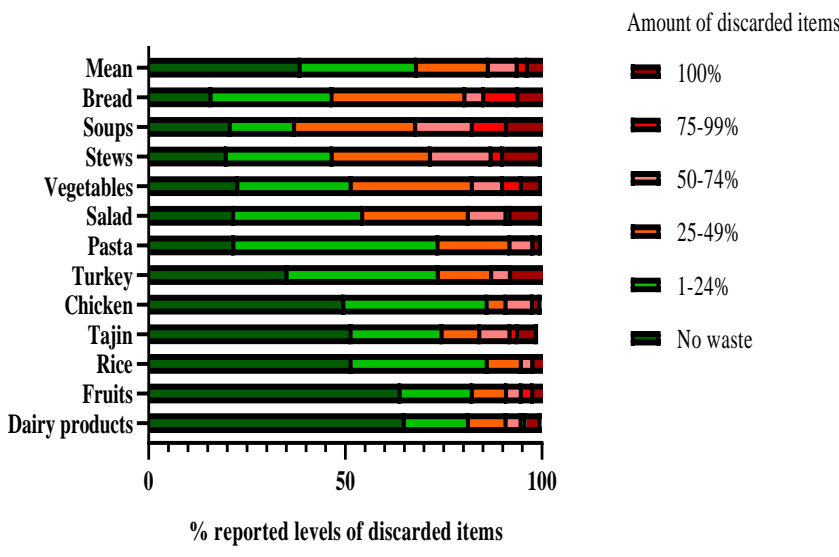

Figure 2. Self-reported ratio of discarded food per food category before (A: sample 1, $\mathrm{n}=154$ students) and after implementing COVID-19 safety measures (B: sample 2, n=143 students)

Concerning the bread, only 13\% (sample 1) and 16\% (sample 2) of respondents declared not throwing away the bread, although the bread portion size was considered as correct by $64 \%$ of respondents and as large by 29\% (Figure 2). About 58\% of respondents (sample 2) stated that the bread portion size was a driver to waste it.

Interestingly after meal consumption, a large majority ( $96 \%$ of sample 2 ) declared to thrown away the service bag in a garbage bin, while $4 \%$ affirmed to not take care of it, once the meal consumed.

\section{DISCUSSION}

The present study aimed in determining the effect of COVID-19 measures on customers' overall food quality perception in the University canteen « Les Jardins » and its impact on food wastage. COVID-19 crisis has led to implement control measures in the University (measuring students temperature at entry, obligation of wearing protection mask, availability of hydro alcoholic gel) in order to limit the virus spread, to protect the health and safety of students, faculty and staff, and to maintain environments that are as safe as possible. These measures were also applied and highlighted at the canteen scale. To adapt its services to current situation challenges, the canteen provided take-out meal bags as this could present lower risks of virus transmission than eating meals in the dining hall: Added 
to safety prevention, customers were not around others for long periods of time and social distancing was guaranteed.

Our data clearly showed that the implementation of safety measures and take-out meals in the canteen has led to a better customer satisfaction regarding quality of food items and service (Table 2). Similarly, Kajenthiran and Karunanithy (2015), and Serhan and Serhan (2019) have established that the quality of service constitutes a strongest predictor of customer satisfaction in Higher Education Institutions. Kursunluoglu (2014) has established that customer services are intangible or tangible value increasing activities which are related with products or services indirectly or directly to meet customer expectations and then to provide customer satisfaction. Our results indicated that this new take-out service was greatly appreciated by students and along with safety measures, it has allowed to increase canteen visits (Table 1). In addition to be safe (Thanks to adapted control measures at university and canteen), take-out meals are very popular among young consumers, because of its convenience (Liu and Chen, 2019). They also improved food presentation: usually meal distribution was made in old irontrails by kitchen employees. Zellner et al. (2014) have established the importance of the food presentation for customers' satisfaction. Furthermore, customers reported a positive impact of COVID19 measures on food hygiene, on variety in food items, and to a lesser extent on sensory quality. Perception of food quality is based on external factors such as appearance, size or color, texture and flavor and internal factors, such as nutritional, hygienic, chemical and physical parameters (Galabo, 2019). These factors contribute to evaluate quality of food products. Several studies have shown the importance of food quality aspects such as careful handling and cleanliness, quality offered and menu variation for students dining at the University canteens (Kim and Kim, 2004; Mui et al., 2014).

Our study has established an association between perception of food quality and food presentation as well as with food safety. Our results are consistent with those of Kim and Kim (2004), Mui et al. (2014) and Galabo (2019) showing that customers' satisfaction in a University canteen was affected mostly on the quality of meals, diversity of food, food hygiene and environment. According to Azni et al. (2019), hygiene is the most important aspect in food service. Food safety has become an increasingly important concern in the COVID-19 pandemic context, as shown in our study. Consumers pay more attention to the related quality issues, since Zaibet et al. (2004) have pointed out concerns about hygiene among other quality attributes and strong awareness about quality and quality assurance schemes in Tunisia. During COVID-19 crisis, food manufacturers and providers are pursuing to practice good manufacturing practices and in particular through cleaning and sanitation of food processing equipment and facilities. They are focusing on five key categories: processes, products, people, premises, and procedures (WHO, 2020a). They also are reinforcing risk-based food safety plans, such as HACCP, and in particular workers safety plans. Open and transparent development of food law as well as information to the public about food related hazards can help to maintain and enhance consumer confidence in the 
safety of food (de Jonge et al., 2008). The World Health Organization has stated the lack of evidence for food or food packaging to be a likely source or route of transmission for the COVID-19 disease (WHO, 2020b). This information was widely relayed and popularized by the Tunisian government (Ministry of Public Health, 2020). According Ali and Mohamed (2014), Kajenthiran and Karunanithy (2015), and Galabo (2019) customers' satisfaction was correlated to subdimensions of service quality such assurance, reliability and responsiveness. This has probably contributed to the positive perception of food quality and service, since a majority of respondents stated their intention to continue having their meals at the university canteen, In a COVID-19 context, restaurant workers had to follow cautiously the safety measures, their behavior would have probably given customers confidence in the University canteen and all the safety measures in the preparation and handling of foods, including regular disinfection and cleaning, made customers feel safe.

The implementation of take-out meals has also improved in a lesser extent, students' satisfaction in terms of sensory quality of food products, variety of food items and the portion size, since the mean scores have increased from poor (MS 1.8) to average (MS 2.5). Although meal recipes and food preparation are in accordance with food health and safety regulatory standards, no spices were used for food preparation, whereas Tunisian kitchen is characterized by its distinctive spiciness. Thus, spicy taste is among criteria influencing customers' preference, particularly in case of young consumers (students) who show growing interest to fast foods (Mat et al., 2016). Quality of food products can then be improved by possible strategic implementations including paying more attention to the sensory quality, proposing more variety of nutritious products, and adjusting the serving portion (Kjøllesdal et al., 2011; Galabo, 2019; Serhan and Serhan, 2019).

Interestingly, our study has shown an increased awareness on food wastage among students before as well as after COVID-19 lockdown lifting, since respondents claimed to avoid (28\%) or reduce (55\%) their food wastage since the COVID-19 crisis. Our results are in accordance with Abeliotis et al. (2014), Martinengo (2014), and Jribi et al. (2020) showing increased levels of awareness and changes in attitudes, towards food waste during times of crisis. During COVID-19 pandemic, consumers tended to make better use of available food supplies (Jribi et al., 2020). This high level of awareness about the food waste constitutes an important condition for a future behavior change (Sarkis et al., 2020). Leaving a portion of the meal uneaten, known as plate waste, is a serious concern for food services like university canteens. The COVID-19 measures have led to a decline of $21 \%$ in self-reported food wastage. However, the percentage of food wastage (73\%) was still high. Similarly, Ozcicek-Dolekoglu and Var (2019) have shown that in Turkish university dining halls, the biggest amount of waste derived from the students (74\%), when compared to Faculty staff. This was in agreement with WRAP (2013), Neff et al. (2015) and Aschemann-Witzel et al. (2015; 2018) pointing out that youths reported more waste of food, challenging environmental sustainability. An average of $33 \%$ of respondents reported they were not 
finishing more than $25 \%$ of served food products in the canteen (Figure 1). This amount of self reported wasted food was higher than that found by Ozcicek-Dolekoglu and Var (2019). Meanwhile, MondéjarJiménez et al. (2016) have established that $1.7 \%$ of Italian youths and $2 \%$ of Spanish youths wasted more than $30 \%$ of their purchased food. Our results indicated that dairy products, fruits, rice, Tunisian dish tajin and chicken were the least wasted or not wasted, whereas the most wasted food group in the canteen was bakery products, followed by vegetables and soups and to a lesser extent, turkey, and salad. Bread is the most wasted food item in Tunisia, because of its subsidizing by a Government's general compensation fund system and cultural eating habits (INC, 2017). In Chinese university canteens, staple foods and vegetables contributed the most to food waste (Wu et al., 2019). WRAP (2011) has also pointed out that fruit, vegetables and "mixed" (pizza, cottage pie and spaghetti bolognaise) were found to be the dominant fractions of the food waste in British schools. According to Tunisian National Institute for Consumption (INC, 2017), households waste about $16 \%$ for bread, $10 \%$ for cereal products (pasta and couscous) and 6\% for vegetables. Similarly, Jribi et al. (2020) have found that during the COVID-19 lockdown, the most wasted food products were bakery products and vegetables in Tunisian households.

Our findings suggest that the amount of food waste could be due to the fair sensory quality of food products, the lack of variety, as well as the portion size. Wu et al. (2019) have also reported that food waste in University canteens was related to problems in food quality and quantity. According to Guthrie and Buzby (2002), WRAP (2013) and Painter et al. (2016), poor food quality, over-serving, lack of preferred food options and the inability to control the serving portions were drivers to plate waste. Cheap ticket prices can also be a factor fostering students' food wastage. The ticket price is US $\$ 0.07$ corresponding in Tunisia, to price of a French baguette. In fact, a study of Papargyropoulou et al. (2019) has pointed out that the least wasteful restaurants are those where the customers paid according to what they consumed. Furthermore, the concept of take-out as convenience food has been identified to become one of the key determinants of overconsumption and waste (Aschemann-Witzel et al., 2018). According Liu and Chen (2019), takeaway food consumption can generate large amounts of food wastes and approximately 0.3 billion wasted meal boxes and plastic bags per day. However, they offered the opportunity to reduce food waste by keeping the leftovers in fridges for future meals or reusing the meal boxes, disposable plastic cutlery and bags. Liu and Chen (2019) have suggested that takeaway food was not always in relation to a wasteful lifestyle. Students could eat them later at home. Therefore, customers' behaviors and habits can also affect post consumption food wastage (Aschemann-Witzel et al., 2015). Several food waste interventions based on education have been conducted in university canteens and dining halls (Reynolds et al., 2019). Positive educational and awareness messages can lead to positive behaviors toward food waste (Lazell, 2016; Pinto et al., 2018; Ellison et al., 2019). They can contribute to maintain the positive COVID-19 driven behaviors towards food waste prevention. According to Wilkie et al. (2015), these interventions can promote pro-environmental behavior beyond 
the universities, as students could convey food waste reduction information to their parents, families and communities.

Taken together, our study has shown the positive influence of COVID-19 safety measures on perception of quality of food products and service in the University canteen, and on consumers' awareness and attitude towards food waste. Similar findings were observed by Jribi et al. (2020), Pappalardo et al. (2020), Principato et al. (2020) and Rodgers et al. (2021) during COVID-19 crisis. Our findings suggest that people's behavioral changes during this COVID-19 pandemic could evolve towards environmental sustainability and social responsibility (Severo et al. 2021), although its implication on sustainability has not yet been observed. According to Sarkis et al. (2020), it would contribute to accelerate sustainability transitions and profound and to promote pervasive social changes towards sustainable supply and production in the coming months and years post-crisis.

Despite these interesting findings, our study has several limitations. There were related to the lack of representativeness in Tunisia and the design of survey using face to face questionnaire. Since this work has been performed in only one canteen, it should then be interpreted cautiously. Also, the distribution face to face of the survey questionnaire might affect participant responses through interviewer bias. For instance, according to van Geffen et al. (2020), survey respondents have the tendency of under-reporting their waste levels and in contrast, of over-reporting their awareness. Moreover, future researches should be conducted to replicate this work on other Tunisian university canteens.

\section{Conclusion}

COVID-19 pandemic induced considerable changes in canteen practices, particularly, In the present work, because of COVID-19, safety measures were taken to limit virus spread, to protect students, faculty and workers, and to improve food safety, including serving meals in a hygienic and convenient manner. Most of students have highly appreciated this new concept based on take-out meals and noticed improvements in the quality of food items and service, in particular in terms of food safety and convenience. The COVID-19 crisis has positively impacted the students' awareness about food wastage since at least two third claimed to have reduced their food waste levels. Although these measures led to a decrease of $21 \%$ in self reported food wastage, it was still important (73\% of respondents), impairing sustainability. Since meals were served in take away containers, uneaten portions in containers could be eaten later. In conclusion, our study has shown that providing good takeout meals has potential for reducing food wastage among students, strengthening the importance of food safety and convenience as effective tools for food waste prevention. Meanwhile, further investigation needs to be carried out about the economical impact of take-out meals (as packaging is not reused) as well as environmental one in terms of thrown packaging. Altogether, our findings have pointed out the need to implement intervention strategies for food waste reduction, through a combination of 
educational, technical and administrative measures. They have to take in account not only contextual factors but also personal attributes. Among them, campaigns should address information and awareness of the environmental and economic consequences of wasting food.

\section{Acknowledgement}

We would like to thank director and all staffs of canteen "Les Jardins" (Tunis) for their kind support during this research, as well as all the survey participants.

\section{REFERENCES}

Abeliotis, K., Lasaridi, K., \& Chroni, C. (2014). Attitudes and behaviour of Greek households regarding food waste prevention. Waste Management \& Research, 32(3), 237-240.

Ali, A. Y. S., \& Mohamed, A. I. (2014). Service Quality Provided by Higher Education Institutions in Somalia and Its Impact on Student Satisfaction. European Journal of Business and Management, 6(11), 143-148.

Aschemann-Witzel, J., De Hooge, I., Amani, P., Bech-Larsen, T., \& Oostindjer, M. (2015). Consumer-related food waste: Causes and potential for action. Sustainability, 7(6), 6457-6477.

Aschemann-Witzel, J., Giménez, A., \& Ares, G. (2018). Convenience or price orientation? Consumer characteristics influencing food waste behaviour in the context of an emerging country and the impact on future sustainability of the global food sector. Global Environmental Change, 49, 85-94.

Azni, I. N., Giyatmi, G., \& Amelia, J. R. (2019). Study Of Customer Satisfaction At Canteen Of Sahid University-Jakarta. Green Development In Industrial Comunity 4.0, 2(1), 627-631. Retrieved from https://core.ac.uk/download/pdf/270240753.pdf

Bachta, M.S. (2011). La Céréaliculture en Tunisie: Une politique de régulation à repenser. Les notes d'analyse du CIHEAM, 4, 1-18.

Baig M. Z., Al-Zahrani K. H., Schneider F., Straquadine G. S. \& Mourad M. (2019). Food waste posing a serious threat to sustainability in the Kingdom of Saudi Arabia - A systematic review. Saudi Journal of Biological Sciences, 26(7), 1743-1752.

Blackbun S. (2019). Reducing food waste on campus. Colleges compost, donate leftovers, control serving portions and install compacting machinery. Retrieved from: https://universitybusiness.com/universityfood-waste-programs-food-waste-on-college-campuses/

de Jonge, J., Van Trijp, J. C. M., van der Lans, I. A., Renes, R. J., \& Frewer, L. J. (2008). How trust in institutions and organizations builds general consumer confidence in the safety of food: A decomposition of effects. Appetite, 51(2), 311-317.

Deluzarche C. (2020). World food trends to follow (or not) until 2030. Futura santé. Retrieved from: https://www.futura-sciences.com/sante/actualites/nutrition-tendances-alimentation-mondiale-suivreou-pas-jusquen-2030-76795

Durante, K.M. (2016). The effect of stress on consumer saving and spending. Journal of Marketing Research, $53,814-828$. 
EHS Environmental Health and Safety. University of Washington. (2020). COVID-19 prevention: Enhanced cleaning and disinfection protocols. Retrieved from: https://www.ehs.washington.edu/system/files/resources/cleaning-disinfection-protocols-COVID19.pdf

Ellison, B., Savchenko, O., Nikolaus, C. J., \& Duff, B. R. (2019). Every plate counts: Evaluation of a food waste reduction campaign in a university dining hall. Resources, Conservation and Recycling, 144, 276-284.

Falasconi, L., Vittuari, M., Politano, A. \& Segrè, A. (2015). Food waste in school catering: an Italian case study. Sustainability, 7(11), 14745-14760.

FAO (2011). Global Food Losses and Food Waste. Extent, Causes and Prevention. FAO, Rome, Italy. 37 p.

FAO (2015). Regional Strategic Framework for Food Loss and Waste Reduction in the Near East North Africa. Retrieved from http://www.fao.org/3/a-i4545e.pdf.

FAO (2018). Conférence sur « Le gaspillage alimentaire en Tunisie : enjeux et voies de réduction ». Retrieved from http://www.fao.org/neareast/news/view/fr/c/1177555/

Galabo, N. R. (2019). Canteen service quality and student satisfaction. International Journal of Scientific \& Technology Research, 8(6), 114-26.

García-Herrero L., De Menna F., Vittuari M. (2019). Food waste at school. The environmental and cost impact of a canteen meal. Waste Manag. 100,249-258.

Güner R., Hassanoglu I., \& Aktas F. (2020). COVID-19: Prevention and control measures in community. Turkish Journal of Medical Sciences. 50, 571-577.

Guthrie, J.F., \& Buzby, J. C. (2020). COVID-19: Prevention and control measures in community Several Strategies May Lower Plate Waste in School Feeding Programs. Food Review, 25(2), 36-42.

INC (2017). Principaux résultats des enquêtes et sondages sur le gaspillage alimentaire. Ressource document. Retrieved from http://inc.nat.tn/fr/principaux-r\%C3\%A9sultats-des-enqu\%C3\%AAtes-etsondages-sur-le-gaspillage-alimentaire.

INC (2018). Le gaspillage alimentaire en Tunisie: le volume et les moyens de lutte. Retrieved from: http://inc.nat.tn/fr/s\%C3\%A9minaire-sur-\%E2\%80\%98\%E2\%80\%99le-gaspillage-alimentaire-entunisie-le-volume-et-les-moyens-de-lutte $\%$ E2\%80\%99\%E2\%80\%99.

Jribi, S., Ben Ismail, H., Dogui, D. \& Debbabi, H. (2020). COVID 19 virus outbreak lockdown: What impacts on household food wastage? Environment, Development and Sustainability, 22, 3939-3955.

Kajenthiran, K. \& Karunanithy, M. (2015). Service Quality and Student Satisfaction: A Case Study of Private External Higher Education Institutions in Jaffna, Sri Lanka. Journal of Business Studies, 1(2), 46 - 64. Retrieved from: https://www.researchgate.net/publication/319112052_Service_Quality_and_Student_Satisfaction_A _Case_Study_of_Private_External_Higher_Education_Institutions_in_Jaffna_Sri_Lanka

Kim, W. G., \& Kim, H. B. (2004). Measuring Customer-based Restaurant Brand Equity. Cornell Hotel and Restaurant Administration Quarterly, 45(2), 115-131.

Kjøllesdal, M. R., Holmboe-Ottesen, G. \& Wandel, M. (2011). Frequent use of staff canteens is associated with unhealthy dietary habits and obesity in a Norwegian adult population. Public Health Nutrition, 14(1), 133-141. 
Kursunluoglu, E. (2014). Shopping centre customer service: creating customer satisfaction and loyalty. Marketing Intelligence \& Planning, 32(4), 528-548.

Lazell, J. (2016). Consumer food waste behaviour in universities: Sharing as a means of prevention. Journal of Consumer Behaviour, 15(5), 430-439.

Liu, C., \& Chen, J. (2019). Consuming take-away food: Convenience, waste and Chinese young people's urban lifestyle. Journal of Consumer Culture, Retrieved from https://doi.org/10.1177/1469540519882487.

Lorenz, B.A.S., Hartmann, M. \& Langen, N. (2017). What makes people leave their food? The interaction of personal and situational factors leading to plate leftovers in canteens. Appetite, 116, 45-56.

Martinengo, M. C. (2014). Household food waste and consumer culture: Reflections on Italian behaviour. Journal of Nutritional Ecology and Food Research, 2(1), 73-77.

Mat, R.C., Zulquernain, N.S., \& Mohd Zaid, N.A. (2016). Profiling of Malaysian young consumers towards fast foods consumptions. Journal of Applied Environemental and biological Sciences, 6, 20-27.

Mahjoub, O., Jemai, A., \& Haddaoui, I. (2020). Waste Management in Tunisia - What Could the Past Bring to the Future?. In: Negm, A., \& Shareef, N. (eds) Waste Management in MENA Regions. Springer Water. Springer, Cham. https://doi.org/10.1007/978-3-030-18350-9_3

Ministry of Agriculture, Tunisia (2020). Oussama Al-Khuraiji reassures the Tunisians of the availability of all agricultural products in the required quantities. Retrieved from http://www.agriculture.tn/?p=16327.

Ministry of Public Health, Tunisia (2020). Tout savoir le Coronavirus. 2020. Retrieved from http://www.santetunisie.rns.tn/fr/toutes-les-actualites/1059-tout-savoir-sur-le-coronavirus.

Mondéjar-Jiménez, J. A., Ferrari, G., Secondi, L., \& Principato, L. (2016). From the table to waste: An exploratory study on behaviour towards food waste of Spanish and Italian youths. Journal of Cleaner Production, 138, 8-18.

Mui Ling D. C., Norazah Mohd S. \& Nalini A. (2014). A Structural Approach on Students' Satisfaction Level with University Cafeterias. Asian Social Science, 10(18), Retrieved from doi:10.5539/ASS.V10N18P202

Neff, R. A., Spiker, M. L., \& Truant, P. L. (2015). Wasted food: US consumers' reported awareness, attitudes, and behaviors. PloS one, Retrieved from https://doi.org/10.1371/journal.pone.0127881.

Ozcicek-Dolekoglu, C., \& Var, I. (2019). Analysis of food waste in university dining halls: A case study from turkey. Fresenius Environ. Bulletin, 28, 156-166.

Painter, K., Thondhlana, G., \& Kua, H. W. (2016). Food waste generation and potential interventions at Rhodes University, South Africa. Waste Management, 56, 491-497.

Pappalardo, G., Cerroni, S., Nayga Jr, R. M., \& Yang, W. (2020). Impact of Covid-19 on Household Food Waste: The Case of Italy. Frontiers in nutrition, 7, 291.

Pinto, R. S., dos Santos Pinto, R. M., Melo, F. F. S., Campos, S. S., \& Cordovil, C. M. D. S. (2018). A simple awareness campaign to promote food waste reduction in a University canteen. Waste management, $76,28-38$. 
Principato, L., Secondi, L., Cicatiello, C., \& Mattia, G. (2020). Caring more about food: The unexpected positive effect of the Covid-19 lockdown on household food management and waste. Socio-Economic Planning Sciences, 100953.

Rodgers, R. F., Lombardo, C., Cerolini, S., Franko, D. L., Omori, M., Linardon, J., Guillaume, S., Fischer, L., \& Fuller-Tyszkiewicz, M. (2021). "Waste not and stay at home" evidence of decreased food waste during the COVID-19 pandemic from the US and Italy. Appetite, 160, 105110.

Sarkis, J., Cohen, M. J., Dewick, P., \& Schröder, P. (2020). A brave new world: Lessons from the COVID19 pandemic for transitioning to sustainable supply and production. Resources, conservation, and recycling, 159: 104894. doi: 10.1016/j.resconrec.2020.104894

Sassi, K., Capone, R., Abid, G., Debs, P., El Bilali, H., Bouacha, O. D., \& Terras, D. S. (2016). Food wastage by Tunisian households. Agrofor, 1(1), 172-181.

Serhan, M. \& Serhan, C. (2019). The Impact of Food Service Attributes on Customer Satisfaction in a Rural University Campus Environment. International Journal of Food Science, doi:10.1155/2019/2154548

Severo, E. A., De Guimarães, J. C. F., \& Dellarmelin, M. L. (2021). Impact of the COVID-19 pandemic on environmental awareness, sustainable consumption and social responsibility: Evidence from generations in Brazil and Portugal. Journal of Cleaner Production, 286, 124947.

Soares Pinto R., Machado Dos Santos Pinto R., Fochat Silva Melo F., Santos Campos S., \& Marques-DosSantos Cordovil C. (2018). A simple awareness campaign to promote food waste reduction in a University canteen Waste Manag. 76:28-38. doi: 10.1016/j.wasman.2018.02.044.

United Nations. (2014). The state of the world population in 2014. A concise report. New York. https://www.un.org/en/development/desa/population/publications/trends/concise-report2014.asp

Van Geffen L., van Herpen E., \& van Trijp H. (2020). Household Food Waste-How to Avoid It? An Integrative Review. In Närvänen E., Mesiranta N., Mattila M., Heikkinen A. (eds) Food Waste Management. Basingstoke: Palgrave Macmillan. Retrieved from doi.org/10.1007/978-3-030-205614_2.

Visschers V.H.M., Gundlach D. \& Beretta C. (2020). Smaller servings vs. information provision: Results of two interventions to reduce plate waste in two university canteens. Waste Management, 103, 323-333.

Wang, C., Pan, R., Wan, X., Tan, Y., Xu, L., Ho, C.S. \& Ho, R.C. (2020). Immediate psychological responses and associated factors during the initial stage of the 2019 coronavirus disease (COVID-19) epidemic among the general population in China. International Journal of Environmental Research and Public Health, 17(5), 1729.

WFP (2019). Hunger Map. Retrieved from https://www.wfp.org/publications/2019-hunger-map

World Health Organization WHO (2020a). COVID-19 and food safety: guidance for food businesses. Retrieved from: https://apps.who.int/iris/bitstream/handle/10665/331705/WHO-2019-nCoVFood_Safety-2020.1-eng.pdf

World Health Organization WHO (2020b). Coronavirus Disease (COVID-19) Pandemic. Retrieved from https://www.who.int/emergencies/diseases/novel-coronavirus-2019.

WRAP (2011). Consumer insight: date labels and storage guidance. Technical. Retrieved from https://www.wrap.org.uk/sites/files/wrap/Technical\%20report\%20dates.pdf. 
WRAP (2013). Household food and drink waste in the UK 2012. Final report. Retrieved from https://wrap.org.uk/sites/files/wrap/hhfdw-2012-main.pdf.pdf.

Wu, Y., Tian, X., Li, X., Yuan, H., \& Liu, G. (2019). Characteristics, influencing factors, and environmental effects of plate waste at university canteens in Beijing, China. Resources, Conservation and Recycling, 149, 151-159.

Zaibet, L., Bachta, M. S., Lajimi, A., \& Abbassi, M. (2004). Consumers' perception of food product quality in Tunisia. Journal of International Food \& Agribusiness Marketing, 16(2), 165-178.

Zellner, D. A., Loss, C. R., Zearfoss, J., \& Remolina, S. (2014). It tastes as good as it looks! The effect of food presentation on liking for the flavor of food. Appetite, 77, 31-35. 